\title{
Considering equity in wildfire protection
}

\author{
Matthew R. Auer ${ }^{1}$ (1)
}

Received: 3 June 2021 / Accepted: 8 August 2021 / Published online: 31 August 2021

(C) The Author(s), under exclusive licence to Springer Japan KK, part of Springer Nature 2021

\begin{abstract}
Climate change, drought, forest pest infestations, and pathogens, and high fuel loadings all factor into the expansion of territory in the United States deemed high-risk for high-intensity wildfire. Risks also mount as a decades-long demographic shift plays out, with individuals and families relocating from urban centers to more sparsely populated, vegetated areas on the margins of cities and towns-a trend that accelerated during the COVID-19 pandemic. As some insurance carriers cease underwriting homeowners insurance in wildfire-prone areas, property owners can be expected to shoulder more costs for home hardening. The equity implications of who pays to fireproof homes and neighborhoods will intensify as wildfire risks multiply in areas beyond the comparatively wealthier wildland-urban interfaces (WUI) of the Pacific coastal states. Systems of polycentric governance, consisting of problem-solving actors who collaborate across jurisdictional and geographical boundaries, can help make wildfire mitigation more equitable. Polycentric governance institutions already help communities adapt to destructive wildfire in the United States. Lessons learned from these institutions must be tailored to poor and marginalized communities in harm's way-with a sense of urgency.
\end{abstract}

Keywords Wildland fire $\cdot$ Wildland-urban interface $\cdot$ Polycentric governance $\cdot$ Firewise $\cdot$ Homeowners insurance

\section{Introduction}

\section{The wildland-urban interface and pandemic migration}

With 1960 as a starting point, the year 2020 ranked second in terms of total acres burned per annum by wildfire according to the Congressional Research Service (2021). Undesirable and erratic wildfire (as opposed to fire managed intentionally for forest health and for the safety of nearby communities) has accelerated in recent years. Since 1960, the three years when wildfires burned at least 10 million or more acres per annum have all occurred since 2014 (CRS 2021; National Interagency Fire Center 2020). In California, through mid-summer 2021, the scale of destruction from uncontrolled wildfires outpaced the totals from a year earlier. From January 1 through July 8, 2021, 4599 fires had burned

Handled by Leslie Mabon, The Open University, United Kingdom.

Matthew R. Auer

Matthew.Auer@uga.edu

1 School of Public and International Affairs, The University of Georgia, 202 Herty Drive, Athens, GA 30602-1492, USA
114.8 million square miles compared with the same time frame in 2020 when 3847 fires consumed 48.6 square miles (Associated Press 2021). Wildfire management, generally, is the single largest item in the U.S. Department of Agriculture (USDA) Forest Service budget on a year-to-year basis. In its FY 2021 budget justification, the agency sought $\$ 2.4$ billion for wildland fire management from a total budget request of $\$ 5.3$ billion (USDA Forest Service 2020).

There are several drivers of high-intensity wildfire, including climate change and drought, build-up of forest fuels following decades of fire-suppression practices, and the spread of pathogens and forest insect pests. Pathogens and forest-damaging insects are often enabled by warmer winters (Abrams 2021). Another major risk factor is the pervasive, widely distributed penetration of homes into the contemporary wildland-urban interface (WUI) (GAO 2019). These areas are where humans and their development intermix with wildland fuel (Stein et al. 2013). The expansion of the WUI is especially evident in the American West, with important implications for the Mountain West and Southwest. Compared to California, wildfires in the mountain states and Southwest have generally been less costly in terms of lives lost and property destroyed because fires frequently occur in rural areas with low population density. That equation is 
changing, as net in-migration to states like Arizona, Colorado, Idaho, and Utah surges (Updater 2021). According to the U.S. Census Bureau (2020), Idaho led all states in population growth between 2019 and July 1, 2020 at 2.12 percent, followed by three other states in the USDA Forest Service's top tier for high-intensity wildfire risk to communities: Arizona at 1.78 percent, and Nevada and Utah at 1.54 and 1.45 percent, respectively. Boise, Idaho exemplifies a location experiencing rapid in-migration combined with heightened wildfire risk. The city's population increased by around 18 percent between 2010 and 2018. Residential construction in Boise has penetrated deeply into wildlands, including the foothills on the city's northern perimeter. ${ }^{1}$

The migration of people from larger cities to smaller towns and rural areas has accelerated during the COVID-19 pandemic. A study by the Federal Reserve Bank of Cleveland found that migration of residents from high-cost, large metro areas to small metro areas, towns, and rural areas increased 9.3 percent in the second, third, and fourth quarters of 2020 (Whitaker 2021). Second home purchases in mountainous, forested areas of the West also accelerated during 2020, with many new residents planning to relocate permanently (Blevins 2020). There are indicators that migration from crowded urban centers to more sparsely populated rural areas will continue. Major growth magnets include Mesa (Arizona), Orem (Utah), Boise, and West Des Moines (Iowa) (National Association of Realtors 2020). All of these locations score high for community wildfire risk, according to the Forest Service Wildfire Risk to Communities database (USDA Forest Service 2021a).

COVID could contribute indirectly to the expansion of people and property in the WUI if re-organized work routines outlast the pandemic. This concern is beginning to inform wildfire risk reduction strategies. In a report on land use planning and wildfire risk in four Western States, Mowery and Punchard (2021) warned that the wildland-urban interface was poised to expand if teleworking becomes more prevalent. Some employers may be persuaded to keep staff dispersed (often, in employees' own homes) and adopt long-term work-from-home or hybrid work arrangements rather than return to a centralized workplace model. This has important implications for who should pay for the costs of wildfire prevention and suppression in the WUI. If the workfrom-home trend endures, employers may face increasing pressure from employees to help bear the costs of complying with local wildfire ordinances or rules imposed by homeowners associations (HOAs). Cost-sharing could cover, for example, the retrofitting of homes with fire-resistant building materials, establishment of defensible perimeters around homes, and other measures.

If residents in the WUI continue to work-from-home, property developers may also come under increasing pressure to cover wildfire protection costs. Local authorities that approve new developments in the WUI may insist on wildfire building codes and fuel reduction measures near building sites. Communities may insist that developers be prohibited from passing on fire-proofing costs to home buyers. Homeowners outside the WUI will also have a stake in these local land-use decisions. Frequently, residents in developed areas outside the WUI pay taxes or fees that help cover the costs of fuel treatment and fire suppression inside the WUI. Hence, outsiders are subsidizing valuable benefits for WUI residents. Facing simultaneous pressure from riskaverse insurance carriers and from cost-conscious taxpayers outside the WUI, homeowners inside the WUI are likely to shift as many fire-proofing costs onto developers as local authorities will consent to.

\section{Hardening homes and neighborhoods: who pays?}

Workers with the option of working from home tend to be in better-paying jobs (Dingel and Neiman 2020). Considering their comparatively higher wealth, salary-earners who work-from-home in the WUI should have a greater capacity to cover some or all costs of home hardening. Whether or not homeowners are prepared to shoulder these costs, the problem of liability for WUI inhabitants is unlikely to dissipate in the years ahead. Insurance carriers in California, for example, are ceasing to insure some residential properties due to wildfire risk. Insurers dropped 235,250 homeowner policies in 2019 - a 31 percent increase over the prior year. Non-renewals were 61 percent higher in zip codes with moderate to very high wildfire risk (Chiglinsky and Chen 2020).

Forcing homeowners in wealthier, wildfire-prone, census tracks to bear more fire-proofing costs may be defensible from a policy perspective. But for poorer districts in harm's way, self-financing home defense is problematic from an equity perspective. In 2020, California's Insurance Commissioner placed a moratorium on nonrenewal of homeowners' insurance in areas affected by wildfire, including in zip codes with comparatively lower median household incomes (California Department of Insurance 2020). While helpful for lower-income households, these moratoria typically lapse after one year. Compounding the problem: California's highrisk insurance pool - the FAIR Plan - is a costly last resort (Chiglinsky and Chen 2020). This plan, which is backed by all admitted insurance carriers in the state, was established to "...provide basic fire insurance coverage for high-risk properties when traditional insurance companies will not" (California FAIR Plan Property Insurance 2021). The president of the FAIR Plan announced a 15.6 percent average rate increase in 2021 for rural clients following a surge in claims in 2020 (Hodson 2020).

Issues of fairness will become acute as wildfire risks mount in poorer, rural areas outside the Pacific Northwest and California. Rural inhabitants east of the wealthy, 
wooded, high-tech warrens in Washington State, Oregon, and California, tend to have fewer financial resources for home hardening. Yet, they face risks comparable to those plaguing the Pacific coastal states, including persistent drought, pest- and pathogen-damaged forests, and build-up of forest fuels. This does not imply that every household in at-risk areas in Washington, Oregon, and California are better equipped to pay for home defense compared to counterpart households in the Mountain West and Southwest. The aftermath of the catastrophic 2018 Camp Fire in Paradise, California testifies to the steep costs many families face to rebuild and to secure new insurance policies (Bartolone 2019). Yet, the median household income of $\$ 51,566$ (2019) in Paradise considerably outpaces family incomes in many at-risk, rural communities in states to the east and south. Consider, for example, that almost the entire territory of the State of New Mexico received an "above normal" fire outlook score (the highest score) for the months of May and June 2021 in the North American Seasonal Fire Assessment and Outlook (National Interagency Fire Center 2021). New Mexico's median household income is the third lowest among 50 states, according to the most recent (2019) U.S. Census data. Or consider Saguache County, Colorado whose forests are contending with a vexing Western Spruce Budworm infestation and frequent droughts. That county's median household income in 2019 was $\$ 38,571$.

So far, in the changing landscape of who pays to protect property from high-intensity wildfire, we have observed several trends, including the likely persistence of work-fromhome norms, post-COVID. As the home and workplace are hybridized, and as well-off workers choose homes in attractive settings in the WUI, we consider the possibility of workers pressuring employers to cover the costs of home hardening. Increasing pressure on property developers in the WUI to internalize fire protection costs seems likely, as well. We observe households grappling with cancelled or non-renewed homeowners insurance and the need to self-finance home defense measures as a pre-condition for replacement coverage. Moratoria on non-renewal of insurance offer a short-term remedy for homeowners, helping to forestall costly, last resort, high-risk pooled insurance. We have argued that affluent property owners are in the best position to harden their homes, but that self-financing is less practicable for many rural inhabitants outside of the wealthy WUI precincts of the Pacific coastal states. We make the case for median household income as a constituent of wildfire comparative risk assessment.

\section{A polycentric approach to wildfire management}

While lower income rural households have fewer resources to mitigate wildfire risks, at least one institutional trend holds promise for improving equity in wildfire protection.
Increasingly, actors at the neighborhood- and householdlevels have multi-actor, multi-scale networks to tap for information and educational resources, technical assistance, and in some cases, limited funding, to help with wildfire safety. These networks are emerging in regions beyond the familiar high-risk Pacific coastal states. While they are not a failsafe for under-resourced communities in the path of potentially destructive wildfires, in many cases, these networks can help homeowners mitigate the worst risks.

Effective wildfire management requires coordination among multiple agencies and actors, at multiple levels. This assertion is the foundation of the National Cohesive Wildland Fire Management Strategy (or "Cohesive Strategy"). The Cohesive Strategy is "... a collaborative process with active involvement of all levels of government and non-governmental organizations, as well as the public..." in finding solutions to the challenges of wildfire management (USDA Forest Service 2021b; National Strategic Committee 2016). At the local level, these strategies are formalized in the provisions of Community Wildfire Protection Plans or CWPPs. CWPPs guide risk identification and risk reduction activities down to the neighborhood level, and in some cases, to the street-level. CWPPs, and the Cohesive Strategy, broadly, are works in progress. According to the USDA. Forest Service, fewer than 10 percent of communities at risk of wildfire have developed CWPPs (US Fire Administration 2020).

Well-designed CWPPs often involve collaborations between different levels of government and with non-state actors. Consider, for example, that the Boulder County CWPP involves federal, state, county, and local entities, as well as 23 separate fire districts. The plan was developed by a multi-stakeholder core team along with contributions from a citizen advisory team and two technical working groups (Core Team 2017a). Boulder's plan and many other multistakeholder, multi-scale CWPPs are akin to polycentric systems of governance - "complex combinations of multiple levels and diverse types of organizations drawn from the public, private, and voluntary sectors that have overlapping realms of responsibility and functional capacities" (McGinnis and Ostrom 2012: 15). Some CWPPs continue to benefit from the active engagement of higher-level participants well after these plans are finalized. Partly for that reason, they hold promise for addressing some of the equity issues described in this essay.

Boulder's CWPP and its technical appendices (Core Team 2017b) are deeply informed by wildfire mitigation measures recommended by a national program called Firewise USA. This program, co-sponsored by the Forest Service and the nongovernmental National Fire Protection Association (NFPA), has features of a polycentric, distributive approach to wildfire protection. Firewise USA is rooted in congressional legislation and spans multiple levels of collaborators. Through a statute passed in 2000 (Secure Rural Schools 


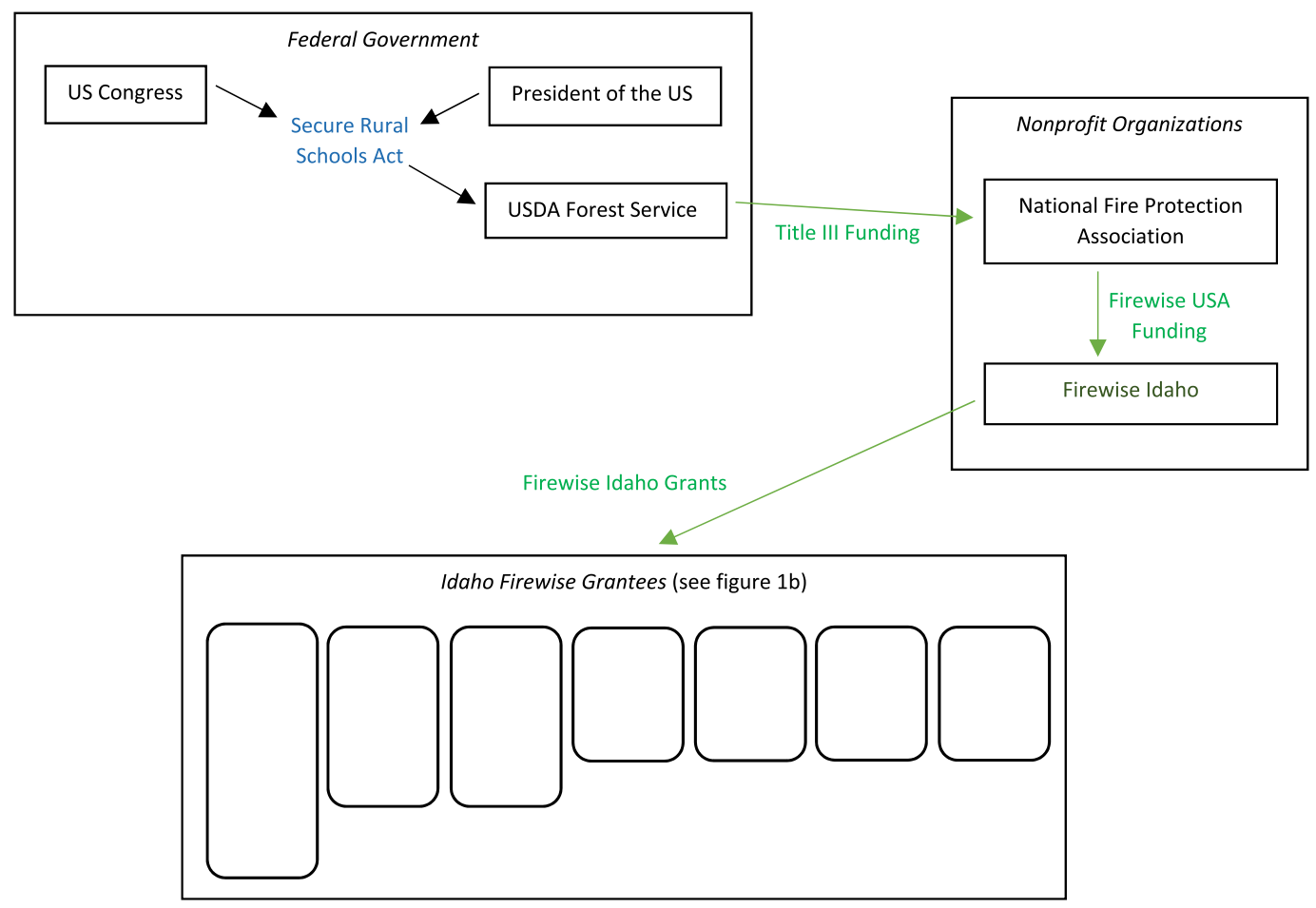

Fig. 1a Polycentric actors supporting the Firewise Idaho program. An enabling act (blue) directs the USDA Forest Service to disburse funds (green) to rural US counties. A nonprofit organization administers the program

Act), Congress directs the Forest Service to redistribute a portion of revenues derived from grazing and timbering fees to county-level actors. Funds may be used for “ “...wildfirerelated education or wildland fire mitigation assistance to homeowners" including fire-resistant home construction and landscaping, community "clean up days," and related activities (USDA Forest Service 2021c). Funds from the Forest Service flow to NFPA which administers Firewise USA. NFPA channels resources to state-level chapters of Firewise, including Idaho's program (Fig. 1a).

The funds are expected to be spent at the county level. However, stakeholders from multiple levels may be collaborators in grant-funded activities (Fig. 1b).

To illustrate, in 2015, an Idaho Firewise grant supported a troupe of performing artists who produced an educational program in collaboration with three federal level agencies (Idaho Firewise 2021). Other Idaho Firewise grants have supported city fire departments, neighborhoods, and state conservation districts on behalf of communities on activities ranging from woody debris removal and home evaluations to community education programs. Grantees and beneficiaries span neighborhood associations, Tribal governments, professional associations (e.g., Idaho Fire Chiefs), and non-governmental organizations (e.g., Project Learning Tree Idaho). ${ }^{2}$ Individual households are often the ultimate end-user, with participants pitching in to reduce hazardous fuels in neighborhood common areas, hardening homes against fire, and learning safe outdoor cooking and campfire practices.

In other contexts in Idaho, homeowners associations perform essential wildfire management functions at the neighborhood level. To illustrate, Hidden Springs, a community in the foothills near Boise, adopted several wildfire mitigation measures in the Hidden Springs HOA covenants, conditions, and restrictions. These measures became part of the Ada County Zoning Ordinance. Rules require, for example, onsite water storage and flow rate requirements (for fire suppression), roads that can accommodate emergency vehicles, and homes outfitted with noncombustible roofing materials (Miller et al. 2017). In this example of polycentric governance, an association of private homeowners self-imposed a set of wildfire mitigation obligations, and those rules were incorporated into a county-level regulation.

Agencies with wildfire management responsibilities, at all levels, must carefully consider fairness and efficiency in how the costs of wildfire safety are distributed. Relevant factors can include the income of residents, location of firefighting services, terrain, and other variables. In the case of Hidden Springs HOA, many wildfire management costs could be justifiably borne at the neighborhood and household levels, considering homeowners' self-selection to live in/near wildlands and considering the income strata of these residents. These investments would be less feasible for lower-income 


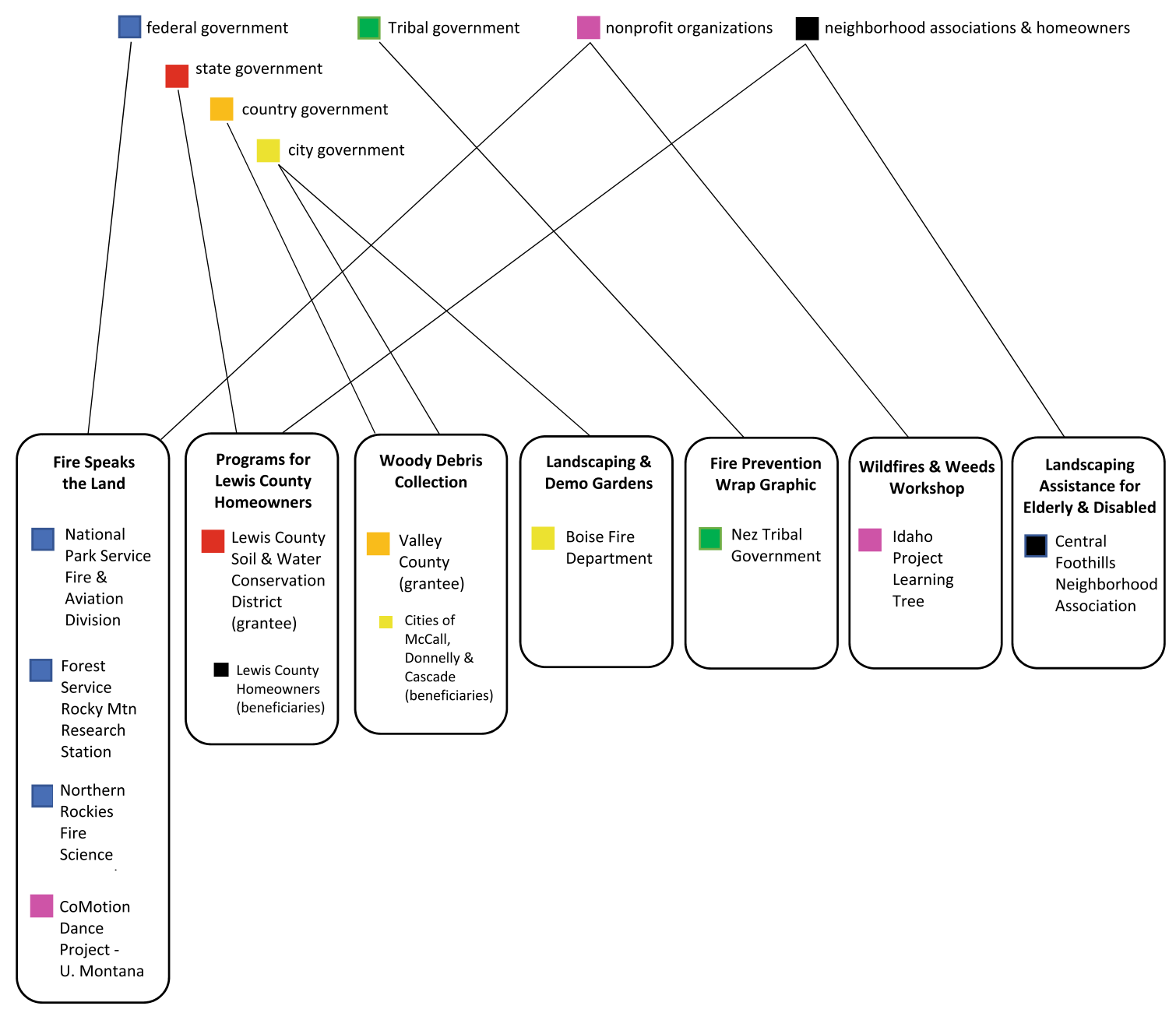

Fig. 1b Idaho Firewise grant activities and polycentric collaborations

households in rural areas. In many parts of Idaho, for example, there is overlap between counties with comparatively low median household income and communities with high wildfire risk (e.g., Idaho, Lemhi, and Owyhee Counties). Polycentric actors at the state, county, and local levels, assisted by nongovernmental organizations, could support under-resourced households with home hardening and community education grants - akin to Firewise. To promote equity in wildfire mitigation, positive incentives (and not just negative inducements, like fines) are necessary.

\section{Summary}

Polycentric governance to pre-empt and respond to highintensity wildfires is, arguably, the only workable system for prevention and suppression of unplanned, erratic wildfires. The presence of private property on the margins of public lands and the ever-growing patchwork of development in the wildland-urban interface necessitate networks of collaborative partnerships, vertically and horizontally, across jurisdictions, agencies, and inclusive of non-state actors. Increasingly, coordination of management responsibilities implicates individual neighborhoods and households. In some areas, multi-actor networks have developed impressive systems for wildfire prevention and response, and have included HOAs whose bottom-up strategies have been incorporated into local ordinances. Open questions include whether the polycentric approach can be adapted to poorer, rural, at-risk communities that, among other things, lack the resources to harden homes, are less well-organized to advocate for burden-sharing, and whose residents have fewer options for moving and relocating than more affluent homeowners. ${ }^{3}$

There are educational, training, technical assistance, and funding roles that federal agencies can and do play to support wildfire mitigation activities of communities outside the wildfire-prone Pacific coastal states. The Cohesive Strategy, 
spearheaded by the U.S. Departments of Agriculture and Interior, is an action-oriented framework that can channel information and financial resources to communities that need help. Top-down programs like the Idaho Firewise concept are potentially replicable. Subsidies that help harden homes in low-income, wildfire-prone regions are dollars well spent considering the much higher personal safety and financial costs entailed in active wildfire suppression. These equity considerations are unlikely to go away any time soon - a reality that extends beyond the Pacific coastal states, and even beyond the Mountain West, and Southwest. Due to a warming climate, Southern Plains states like Arkansas, Kansas, Oklahoma, and parts of Louisiana and Texas are at heightened risk of a destructive wildfire in the years ahead (Heilman et al. 2015). Many people in the line of wildfire in these regions are at a disadvantage to the comparatively well-resourced WUI inhabitants on the perimeters of major California cities and the planful HOAs on the outskirts of Boise. Now is a good time to adopt a polycentric approach to wildfire management to meet the needs of the most vulnerable.

\section{Notes}

1. The moving and storage company PODS, which tracks the net relocation gains and losses of PODS customers to U.S. cities, found that Boise, Idaho had the highest net gain of all U.S. cities in 2020, with three times more people moving in than moving out (Taylor 2021).

2. Active participation in Firewise USA grants is only one of the important ways that nongovernmental organizations participate in polycentric wildfire mitigation and response activities. In the area of wildfire response, Eriksen and Simon (2017) documented the impact that an advocacy organization, United Policyholders, had in supporting residents of damaged and destroyed properties in the aftermath of the 1991 Oakland Hills Firestorm. United Policyholders helped homeowners navigate complicated and frequently adversarial settlement processes with insurance carriers.

3. More research is also needed to explore how nonmaterial losses differentially affect segments of at-risk communities - for example, people with strong ties to areas where they live. Bihari and Ryan (2012) found that residents who exhibit high levels of place attachment in six fire-prone U.S. communities were more likely to engage in community-based measures to mitigate risks from wildfire. The authors, however, did not control for household income, gender, age, race, ethnicity, legal status, or other measures of social inequality. In contrast, Collins (2008) found that household income among surveyed residents in Arizona's White Mountains was positively correlated with wildfire preparation measures. Compared to more affluent households, poorer residents (including renters and residents in mobile home parks) were less prepared to mitigate wildfire risks.

\section{References}

Abrams J, Huber-Stearns H, Steen-Adams M, Davis EJ, Bone C, Nelson MF, Moseley C (2021) Adaptive governance in a complex social-ecological context: emergent responses to a native forest insect outbreak. Sustain Sci 16:53-68

Associated Press (2021) Pace of California wildfires well ahead of disastrous 2020. https://apnews.com/article/ca-state-wire-calif ornia-wildfires-fires-2fbdc6238266c46c419f48c0b0b635e2. Accessed 17 Aug 2021

Bihari M, Ryan R (2012) Influence of social capital on community preparedness for wildfires. Landsc Urb Plan 106:253-261. https://doi.org/10.1016/j.landurbplan.2012.03.011

Bartolone P (2019) Their home survived the camp fire-but their insurance did not. NPR. https://www.npr.org/2019/02/17/69520 5917/their-home-survived-the-camp-fire-but-their-insurancedid-not. Accessed 17 Aug 2021

Blevins J (2020) The great urban exodus: Colorado resort towns see flood of second-home buyers, burst in school enrollment. Colorado Sun. https://coloradosun.com/2020/07/27/urban-exoduscolorado-resort-towns-second-home-buyers-school-enrollment/. Accessed 17 Aug 2021

California Department of Insurance (2020) Wildfire response and readiness. https://www.insurance.ca.gov/01-consumers/200-wrr/. Accessed 17 Aug 2021

California FAIR Plan Property Insurance (2021) California FAIR Plan Property Insurance homepage. https://www.cfpnet.com/. Accessed 17 Aug 2021

Chiglinsky K, Chen E (2020) Many Californians being left without homeowners insurance due to wildfire risk. Insurance J. https:// www.insurancejournal.com/news/west/2020/12/04/592788.htm. Accessed 17 Aug 2021

Collins TW (2008) What influences hazard mitigation? Household decision making about wildfire risks in Arizona's White Mountains. Prof Geogr 60:508-526

Core Team (2017a) Boulder county community wildfire protection plan. https://assets.bouldercounty.org/wp-content/uploads/2017/ 02/community-widfire-protection-plan-book-low-resolution.pdf. Accessed 17 Aug 2021

Core Team (2017b) Boulder county community wildfire protection plan appendices. https://assets.bouldercounty.org/wp-content/uploads/ 2017/02/community-wildfire-protection-plan-appendices.pdf. Accessed 17 Aug 2021

CRS (2021) Wildfire statistics. https://fas.org/sgp/crs/misc/IF10244. pdf. Accessed 17 Aug 2021

Dingel JI, Neiman B (2020) How many jobs can be done from home? J Public Econ. https://doi.org/10.1016/j.jpubeco.2020.104235

Eriksen C, Simon G (2017) The affluence-vulnerability interface: intersecting scales of risk, privilege and disaster. Environ Plan A 49:293-313. https://doi.org/10.1177/0308518X16669511

GAO (2019) Wildland fire: federal agencies' efforts to reduce wildland fuels and lower risk to communities and ecosystems. GAO-2052. https://www.gao.gov/assets/710/703470.pdf. Accessed 17 Aug 2021 
Heilman WE, Tang Y, Luo L, Zhong S, Winkler JA, Bian X (2015) Potential climate change impacts on fire weather in the United States. Fire management today 74:22-27. https://www.fs.usda. gov/treesearch/pubs/49749. Accessed 17 Aug 2011

Hodson D (2020) FAIR Plan rates to rise. Mountain democrat. https:// www.mtdemocrat.com/news/wildfire-risk-to-increase-fair-planrates/. Accessed 17 Aug 2021

Idaho Firewise (2021) Idaho firewise grant program. https://idahofirew ise.org/grants/. Accessed 17 Aug 2021

McGinnis M, Ostrom E (2012) Reflections on Vincent Ostrom, public administration, and polycentricity. Pub Admin Rev 72:15-25

Miller SR, Wuerzer T, Vos J, Lindquist E, Mowery M, Holfeltz T, Stephens B, Grad A (2017) Planning for wildlife in the wildlandurban interface: a resource guide for Idaho communities. https:// ssrn.com/abstract=2845046. Accessed 17 Aug 2021

Mowery M, Punchard D (2021) Land use planning approaches in the wildland-urban interface. An analysis of four western states: California, Colorado, Montana and Washington. Community wildlife planning center. https://www.communitywildfire.org/wp-content/ uploads/2021/02/CWPC_Land-Use-WUI-Report_Final_2021.pdf. Accessed 17 Aug 2021

National Association of Realtors (2020) 2020 real estate forecast summit: top ten markets during and in a post-covid environment in 2021-2022. https://cdn.nar.realtor/sites/default/files/documents/ top-ten-markets-during-and-in-a-post-covid-environment-in2021-2022-12-14-2020.pdf. Accessed 17 Aug 2021

National Interagency Fire Center (2021) North American seasonal fire assessment and outlook. https://www.predictiveservices.nifc.gov/ outlooks/NA_Outlook.pdf. Accessed 17 Aug 2021

National Interagency Fire Center (2020) Total wildland fires and acres (1926-2019). https://www.nifc.gov/fireInfo/fireInfo_stats_total Fires.html. Accessed 17 Aug 2021

National Strategic Committee (2016) Cohesive strategy: crosswalk and strategic alignment. https://www.forestsandrangelands.gov/docum ents/strategy/reports/cohesive_strategy_crosswalk_and_strategic_ alignment_report.pdf. Accessed 17 Aug 2021

Stein SM, Comas SJ, Menakis JP, Steward SI, Cleveland H, Bramwell L, Radeloff V (2013) Wildfire, wildlands, and people: understanding and preparing for wildfire in the wildland-urban interface. General technical report, RMRS-GT-299. USDA Forest Service, Washington
Taylor L (2021) Top cities for relocation 2020-21: a look at pandemic moving trends. A blog by PODS. https://www.pods.com/blog/ 2021/04/national-moving-trends. Accessed 17 Aug 2021

Updater (2021) United States migration report: Q1 2021. 6 May 2021. https://res.cloudinary.com/updater-marketing/image/upload/v1620 742673/downloads/relocation\%20trends/Updater_Q1_2021_ Migration_Report_-_FINAL.pdf. Accessed 17 Aug 2021

US Census Bureau (2020) Annual estimates of the resident population for the United States, regions, states, and the District of Columbia: April 1, 2020 to July 1, 2020. Excel spreadsheet. https://www2. census.gov/programs-surveys/popest/tables/2010-2020/state/ totals/nst-est2020.xlsx. Accessed 17 Aug 2021

US Fire Administration (2020) How to create a community wildfire protection program. https://www.usfa.fema.gov/blog/cb-062420. html. Accessed 17 Aug 2021

USDA Forest Service (2021a) Wildfire risk to communities. Database available online at https://wildfirerisk.org/explore/. Accessed 17 Aug 2021

USDA Forest Service (2021b) National cohesive wildland fire management strategy https://www.fs.fed.us/restoration/cohesivestrategy. shtml. Accessed 17 Aug 2021

USDA Forest Service (2021c) Title III FAQS. https://www.fs.usda. gov/working-with-us/secure-rural-schools/title-3-faqs. Accessed 17 Aug 2021

USDA Forest Service (2020) Fiscal year 2021 budget justification. https://www.fs.usda.gov/sites/default/files/2020-02/usfs-fy-2021budget-justification.pdf. Accessed 17 Aug 2021

Whitaker S (2021) Migrants from high-cost, large metro areas during the COVID-19 pandemic, their destinations, and how many could follow. https://www.clevelandfed.org/newsroom-and-events/ publications/cfed-district-data-briefs/cfddb-20210325-migrantsfrom-high-cost-large-metro-areas-during-the-covid-19-pandemic. aspx. https://doi.org/10.26509/frbc-ddb-20210325. Accessed 17 Aug 2021

Publisher's Note Springer Nature remains neutral with regard to jurisdictional claims in published maps and institutional affiliations. 